\title{
The Brazilian version of the 25-Item National Eye Institute Visual Function Questionnaire: translation, reliability and validity
}

\author{
Versão brasileira do questionário de função visual de 25 itens do questionário \\ do National Eye Institute: tradução, confiabilidade $e$ validação
}

\author{
Luciano Mesquita Simão ${ }^{1}$ \\ Marco Aurélio Lana-Peixoto ${ }^{2}$ \\ Carolina Reis Araújo ${ }^{3}$ \\ Marcos Aurélio Moreira ${ }^{4}$ \\ Antônio Lúcio Teixeira ${ }^{5}$
}

Trabalho realizado no Department of Neuro-Ophthalmology, Hospital São Geraldo, School of Medicine, Universidade Federal de Minas Gerais - UFMG - Belo Horizonte (MG) - Brazil.

Post Graduate Student, Universidade Federal de Minas Gerais - UFMG - Belo Horizonte (MG) - Brazil.

Associate Professor of Neurology and Ophthalmology, School of Medicine - UFMG - Belo Horizonte (MG) Brazil.

3 Post Graduate Student - UFMG - Belo Horizonte (MG) - Brazil.

${ }^{4}$ Post Graduate Student - UFMG - Belo Horizonte (MG) - Brazil.

${ }^{5}$ Associate Professor of Neurology, School of Medicine - UFMG - Belo Horizonte (MG) - Brazil.

Address for correspondence: Luciano Mesquita Simão. Rua Padre Rolim, 769/1301 - Belo Horizonte (MG) CEP 30130-090.

E-mail: lucianosimao@gmail.com

Recebido para publicação em 26.07.2007

Aprovação em 25.03.2008

\begin{tabular}{l} 
ABSTRACT \\
\hline Purpose: To develop and investigate the reliability and validity of a \\
Brazilian version of the 25-Item National Eye Institute Visual Function \\
Questionnaire. Methods: A Brazilian version of the questionnaire was \\
developed and applied to patients with chronic eye diseases and healthy \\
controls. Reliability was assessed by Cronbach's alpha coefficient, \\
intraclass correlation coefficient and interrater reliability coefficient. \\
Participants were submitted to the Medical Outcomes Study Short Form- \\
36 Questionnaire. Validity was estimated by the correlation between the \\
questionnaires and among the 12 subscales of the questionnaire, subs- \\
cales scores and visual acuity, patients' and controls' subscales scores, \\
and the factor analysis. Responsiveness of the questionnaire was asse- \\
ssed in a group of patients before and following cataract surgery. \\
Results: Cronbach's alpha, intraclass correlation and interrater relia- \\
bility coefficients were highly significant. Validity was well established \\
in all tests. In patients who underwent cataract surgery, a better vision- \\
related quality of life was observed following surgery. Conclusion: The \\
Brazilian version of the 25-Item National Eye Institute Visual Function \\
Questionnaire has valid and reliable psychometric properties and can be \\
applied to vision-related quality of life research.
\end{tabular}

Keywords: Quality of life; Validation studies; Questionnaires; Brazil

\section{INTRODUCTION}

Quality of life is a multidimensional concept of health related to physical, functional, social and psychological domains ${ }^{1}$. Most recently, quality of life has been reported as health-related quality of life (HRQOL) ${ }^{(1)}$. Measures of HRQOL have been used to track outcomes for many diseases, evaluate the effect of their symptoms and treatment on patients' lives ${ }^{(2-4)}$. The literature on quality-of-life measurement includes both health measures and disease-specific measures ${ }^{(1)}$. General health measures such as the Sickness Impact Profile (SIP) and the Medical Outcomes Study Short Form-36 (SF-36) questionnaires address different populations and cover many health issues ${ }^{(1)}$. However, their power to measure changes in quality of life of patients with specific problems is limited ${ }^{(1)}$. Quality of vision is an integral part of HRQOL and assessment of the dimensions of self-reported vision-related health states has been considered a valuable tool to measure visual impairment ${ }^{(1,5-9)}$. Indeed traditional clinical measures of vision, such 
as Snellen visual acuity and visual field tests may fail to assess many aspects of visual disability that are important for daily activities and well-being ${ }^{(2,10)}$. As the need to develop instruments to measure both general and specific visual disorders has been recognized by the scientific community, in the mid-1990s the National Eye Institute (NEI) funded the development of a vision-specific HRQOL instrument, called the National Eye Institute 51-Item Visual Functioning Questionnaire (NEI VFQ-51) ${ }^{(1)}$. Later on, a shorter version was developed: the NEI VFQ-25, to become useful in clinical practice and improve data quality. This short version has 25 items that measure vision-targeted HRQOL which are grouped into 12 subscales, including a general health rating question ${ }^{(2,10-12)}$. Additionally, 12 optional items are provided for eventual use within specific subscales in case they represent the main dimension of vision-targeted HRQOL ${ }^{(12-13)}$. The composite NEI VFQ-25 score is an unweighted average of the responses to all items except for the general health rating question ${ }^{(12)}$. The composite VFQ-25 has adequate reliability and validity, and subscales scores from the shorter form correlate highly with scores in the long original version ${ }^{(12)}$. Their psychometric properties are similar ${ }^{(13)}$. The NEI VFQ-25 was designed and validated for the American language and culture ${ }^{(13)}$. The translation of a questionnaire into another language can compromise its validity, and cultural and linguistic factors may play a role in modifying the original meaning of a specific question ${ }^{(13)}$. Therefore, even after an adequate process translation into another language, the translated questionnaire must be revalidated to demonstrate that it is equivalent to the original, even in a different cultural environment ${ }^{(2,13-17)}$. To our knowledge, the NEI VFQ-25 has been translated into Japanese ${ }^{(2)}$, Italian $^{(13)}$, French ${ }^{(14)}$, Spanish ${ }^{(15)}$, Turkish ${ }^{(16)}$ and German ${ }^{(17)}$, and validated for use in different populations.

There are few reported studies on visual-related quality of life in the Brazilian population. All of them assessed the impact of a specific eye condition (i.e., penetrating keratoplasty, Stevens-Johnson syndrome, refractive surgery, cataract) on quality of life, using different questionnaires ${ }^{(18-21)}$. The NEI VFQ-25 has been previously translated into Portuguese and applied to a group of cataract patients, although its validation had not been tested ${ }^{(21)}$. As far as we know only the NEI Refractive Error Quality of life has been validated to be used in Brazil $^{(20)}$. We therefore conducted this study to test a Brazilian version of the NEI VFQ-25 questionnaire and investigate its reliability and validity in a group of Brazilian patients with different ophthalmic conditions.

\section{METHODS}

The study was conducted at the Hospital São Geraldo of the Federal University of Minas Gerais Medical School in Belo Horizonte, and included the following phases: translation of the questionnaire into Portuguese, assessment of item comprehension, back translation into English, development of a consensual version, and formal assessment of its reliability and validity ${ }^{(12)}$.

In order to assess the reliability and validity of the translated NEI VFQ-25, we used a sample of five-patient groups with cataract (C), age-related macular degeneration (ARMD), primary open angle glaucoma (POAG), ocular toxoplasmosis (OT) and demyelinating optic neuritis (DON). Controls comprised 11 subjects with no evidence of eye disease and a 20/20 corrected Snellen visual acuity. All surveys were administered by two physicians and the interviews included the Brazilian version of the NEI VFQ-25, 12 optional items about aspects of vision-specific HRQOL, and the SF-36 to measure general HRQOL.

The NEI-VFQ-25 comprises 25 items that measure visiontargeted HRQOL and are grouped into 12 subscales: general health $(\mathrm{GH}, 1$ item); general vision $(\mathrm{GV}, 1$ item); ocular pain (OP, 2 items); difficulty with near-vision activities (NV, 3 items); difficulty with distance-vision activities (DV, 3 items); limitation of social functioning due to vision (SF, 2 items); mental health problems due to vision (MH, 4 items), role limitations due to vision (RL, 2 items); dependency on the others due to vision (DP, 3 items); driving difficulties (DR, 2 items); difficulty with color vision (CV, 1 item); and difficulty with peripheral vision (PV, 1 item). Each subscale score is converted to a score between 0 to 100 , and higher scores indicate better vision-specific HRQOL ${ }^{(22)}$.

The SF-36 was chosen because it is one of the most widely used measures in health services research ${ }^{2,23-25)}$ and has been already translated into the Portuguese language and validated ${ }^{(22)}$. This questionnaire includes 8 subscales: general health, physical function, role limitations due to physical and mental disability, mental health, social function, vitality, and bodily pain. Each of the subscales is scored on a 0 to 100 scale, in which 100 indicates the best possible score and 0 indicates the worst function. All statistical analysis were done with the SPSS version 12 for Windows (SPSS Inc, Chicago, IL).

\section{Reliability}

Cross-sectional data from the five groups of patients with different eye diseases and the controls were used to quantify reliability. Cronbach's alpha coefficient ${ }^{(12)}$ was used as the index of internal consistency for each subscale. To quantify test-retest reliability, intraclass correlation coefficients ${ }^{(2)}$ were used. All study participants were reinterviewed 1 to 2 weeks apart from the first application and interrater reliability was also calculated ${ }^{(26)}$.

\section{Validity}

To assess validity we estimated the statistical significance of three comparisons. The first comparison assessed the correlations between NEI VFQ-25 and the SF-36 subscales ${ }^{(2)}$ applying Spearman's coefficient of correlation.

The second set of comparisons was done by Pearson's coefficient ${ }^{(12)}$ between subscales scores and visual acuity in the better and worse eye of all groups of patients, except the 
DON group, as there were no differences in visual acuity in all subjects in this group (corrected Snellen visual acuity 20/20 OU) ${ }^{(2,12,27)}$. We also compared the subscales scores between patients and controls using Mann-Whitney $U$ test ${ }^{(13)}$. Additionally, to determine the dimensionality of all the scale scores, the interscale nonparametric correlations were calculated by Spearman's correlation coefficient ${ }^{(13)}$.

The third set of statistical tests was performed by factor analysis (FA) to justify the variability of the NEI VFQ-25 results $^{(26)}$. It was assessed using 10 subscales ("General health" and "Driving" were excluded), with varimax rotation with Kaiser normalization ${ }^{(26,28)}$. The "General Health" was not included because it is not taken into consideration for the composite score and is treated as a stand-alone item. The "Driving" subscale was excluded because it was missing in $61 \%$ of the cases ${ }^{(2)}$.

\section{RESULTS}

The study participants comprised 24 women and 12 men with a mean age of 49.9 years (range 18 to 87 ). The LogMAR mean visual acuity was 0.512 in the cataract, 1.052 in the agerelated macular degeneration, 0.402 in the primary open angle glaucoma, 0.674 in the ocular toxoplasmosis, and 0.0 in DON and control groups. Comorbidities were found in 21 subjects (21 high blood pressure, 10 hypercholesterolemia, two depression, one diabetes mellitus - no evidence of retinopathy - and one breast cancer).

\section{Reliability}

Cronbach's alpha coefficient was higher than 0.7 for all of the subscales (range 0.72 for ocular pain to 0.92 for role difficulties). As test-retest reliability is concerned the intraclass correlation coefficient was 0.94 (range 0.60 to 0.97 ). Regarding interrater reliability the intraclass correlation coefficient was 0.96 (range 0.47 to 1.00 ) (Table 1 ).

\section{Validity}

High correlation was found between scores on most of the VFQ-25 subscales and similar domains of the SF-36 (Table 2). The visual acuity of the better eye strongly correlated with the "Near activities" and "Distance activities" subscales which are influenced by central vision, whereas the acuity of the worse eye strongly correlated with "Near activities", "Distance activities" and "Social function" subscales which depend on the quality of vision on daily activities. The "General health", "Ocular pain" and "Color vision" subscales poorly correlated with visual acuity.

The control group had the best scale scores across all dimensions of the NEI VFQ-25. The lowest scores for patients, when compared with controls, were for "Near activities" (53.3 vs 93.9), "Distance activities" (59.6 vs 96.2), "Driving" (53.4 vs 87.1) and "Dependency" (64.6 vs 97.7). All comparisons between subscales scores in the control group and in the group of patients were statistically significant $(p<0.05)$ except for "General health" $(p=0.072)$, "Mental health" $(\mathrm{p}=0.097)$ and "Color vision" subscales $(\mathrm{p}=0.055)$ (Table 3$)$.

Table 4 shows Spearman's correlation coefficients between the 12 subscales of the NEI VFQ-25 questionnaire. For all subscales except for "General health" the $p$ value was consistently lower than 0.05 .

On factor analysis (FA), two factors were obtained: one and two. The "Near activities", "Distance activities", "Social function", "Mental health", "Role difficulty", "Dependency" and "Color vision" subscales were included in factor one. The "General vision", "Ocular pain" and "Peripheral vision" subscales were included in the second factor. The FA accounted for $64.5 \%$ of the total variance. We observed favorable changes in the NEI VFQ-25 overall and subscales composite in the cataract group before and following the cataract surgery (Table 3 ).

\begin{tabular}{|c|c|c|c|c|}
\hline & Number of items & $\begin{array}{c}\text { Cronbach's alpha } \\
\text { coefficient }\end{array}$ & $\begin{array}{l}\text { Intraclass correlation } \\
\text { (test-retest reliability) }\end{array}$ & $\begin{array}{l}\text { Intraclass correlation } \\
\text { (interrater reliability) }\end{array}$ \\
\hline General health & 1 & $N A^{*}$ & 0.60 & 0.87 \\
\hline General vision & 1 & NA & 0.93 & 0.86 \\
\hline Ocular pain & 2 & 0.72 & 0.86 & 0.70 \\
\hline Near activities & 3 & 0.91 & 0.93 & 0.87 \\
\hline Distance activities & 3 & 0.90 & 0.90 & 0.78 \\
\hline \multicolumn{5}{|l|}{ Vision specific: } \\
\hline Social function & 2 & 0.73 & 0.79 & 1.00 \\
\hline Mental health & 4 & 0.82 & 0.94 & 0.76 \\
\hline Role difficulties & 2 & 0.92 & 0.78 & 0.47 \\
\hline Dependency & 3 & 0.88 & 0.97 & 0.78 \\
\hline Driving & 2 & 0.93 & 0.93 & 0.99 \\
\hline Color vision & 1 & NA & ** & 1.00 \\
\hline Peripheral vision & 1 & NA & 0.61 & 1.00 \\
\hline 25-item composite & 25 & 0.87 & 0.94 & 0.96 \\
\hline
\end{tabular}




\begin{tabular}{|c|c|c|c|c|c|c|c|c|}
\hline & \multicolumn{8}{|c|}{ SF-36 } \\
\hline & $\begin{array}{c}\text { Physical } \\
\text { functioning }\end{array}$ & $\begin{array}{c}\text { Role } \\
\text { physical }\end{array}$ & $\begin{array}{l}\text { Bodily } \\
\text { pain }\end{array}$ & $\begin{array}{c}\text { General } \\
\text { health }\end{array}$ & Vitality & $\begin{array}{c}\text { Social } \\
\text { functioning }\end{array}$ & $\begin{array}{c}\text { Role } \\
\text { emotional }\end{array}$ & $\begin{array}{r}\text { Mental } \\
\text { health }\end{array}$ \\
\hline $\begin{array}{l}\text { General health } \\
p\end{array}$ & $\begin{array}{l}0.216 \\
0.21\end{array}$ & $\begin{array}{l}0.256 \\
0.13\end{array}$ & $\begin{array}{l}0.380 \\
0.02\end{array}$ & $\begin{array}{l}0.429 \\
0.01\end{array}$ & $\begin{array}{l}0.398 \\
0.02\end{array}$ & $\begin{array}{l}0.013 \\
0.94\end{array}$ & $\begin{array}{l}0.174 \\
0.31\end{array}$ & $\begin{array}{l}0.191 \\
0.26\end{array}$ \\
\hline $\begin{array}{l}\text { General vision } \\
p\end{array}$ & $\begin{array}{l}0.468 \\
0.01\end{array}$ & $\begin{array}{l}0.455 \\
0.01\end{array}$ & $\begin{array}{l}0.470 \\
0.01\end{array}$ & $\begin{array}{l}0.173 \\
0.31\end{array}$ & $\begin{array}{l}0.329 \\
0.05\end{array}$ & $\begin{array}{l}0.365 \\
\mathbf{0 . 0 3}\end{array}$ & $\begin{array}{l}0.492 \\
0.01\end{array}$ & $\begin{array}{l}0.080 \\
0.64\end{array}$ \\
\hline $\begin{array}{l}\text { Ocular pain } \\
p\end{array}$ & $\begin{array}{l}0.409 \\
0.01\end{array}$ & $\begin{array}{l}0.223 \\
0.19\end{array}$ & $\begin{array}{l}0.574 \\
0.01\end{array}$ & $\begin{array}{l}-0.038 \\
0.82\end{array}$ & $\begin{array}{l}0.263 \\
0.12\end{array}$ & $\begin{array}{l}0.318 \\
0.06\end{array}$ & $\begin{array}{l}0.513 \\
0.01\end{array}$ & $\begin{array}{l}0.143 \\
0.41\end{array}$ \\
\hline $\begin{array}{l}\text { Near activities } \\
p\end{array}$ & $\begin{array}{l}0.351 \\
0.04\end{array}$ & $\begin{array}{l}0.385 \\
0.02\end{array}$ & $\begin{array}{l}0.306 \\
0.07\end{array}$ & $\begin{array}{l}0.116 \\
0.50\end{array}$ & $\begin{array}{l}0.061 \\
0.72\end{array}$ & $\begin{array}{l}0.157 \\
0.36\end{array}$ & $\begin{array}{l}0.451 \\
0.01\end{array}$ & $\begin{array}{l}-0.038 \\
0.83\end{array}$ \\
\hline $\begin{array}{l}\text { Distance activities } \\
p\end{array}$ & $\begin{array}{l}0.237 \\
0.16\end{array}$ & $\begin{array}{l}0.285 \\
0.09\end{array}$ & $\begin{array}{l}0.329 \\
0.05\end{array}$ & $\begin{array}{l}0.160 \\
0.35\end{array}$ & $\begin{array}{l}0.182 \\
0.29\end{array}$ & $\begin{array}{l}0.080 \\
0.64\end{array}$ & $\begin{array}{l}0.351 \\
0.04\end{array}$ & $\begin{array}{l}0.106 \\
0.54\end{array}$ \\
\hline $\begin{array}{l}\text { Social function } \\
p\end{array}$ & $\begin{array}{l}0.260 \\
0.13\end{array}$ & $\begin{array}{l}0.224 \\
0.19\end{array}$ & $\begin{array}{l}0.495 \\
0.01\end{array}$ & $\begin{array}{l}0.217 \\
0.20\end{array}$ & $\begin{array}{l}0.360 \\
\mathbf{0 . 0 3}\end{array}$ & $\begin{array}{l}0.027 \\
0.88\end{array}$ & $\begin{array}{l}0.551 \\
\mathbf{0 . 0 1}\end{array}$ & $\begin{array}{l}0.233 \\
0.17\end{array}$ \\
\hline $\begin{array}{l}\text { Mental health } \\
p\end{array}$ & $\begin{array}{l}0.318 \\
0.06\end{array}$ & $\begin{array}{l}0.351 \\
\mathbf{0 . 0 4}\end{array}$ & $\begin{array}{l}0.648 \\
0.01\end{array}$ & $\begin{array}{l}0.269 \\
0.11\end{array}$ & $\begin{array}{l}0.371 \\
\mathbf{0 . 0 3}\end{array}$ & $\begin{array}{l}0.092 \\
0.59\end{array}$ & $\begin{array}{l}0.532 \\
\mathbf{0 . 0 1}\end{array}$ & $\begin{array}{l}0.316 \\
0.06\end{array}$ \\
\hline $\begin{array}{l}\text { Role difficulties } \\
p\end{array}$ & $\begin{array}{l}0.390 \\
0.01\end{array}$ & $\begin{array}{l}0.241 \\
0.16\end{array}$ & $\begin{array}{l}0.305 \\
0.07\end{array}$ & $\begin{array}{l}0.143 \\
0.41\end{array}$ & $\begin{array}{l}0.125 \\
0.47\end{array}$ & $\begin{array}{l}0.194 \\
0.26\end{array}$ & $\begin{array}{l}0.520 \\
0.01\end{array}$ & $\begin{array}{l}0.213 \\
0.21\end{array}$ \\
\hline $\begin{array}{l}\text { Dependency } \\
p\end{array}$ & $\begin{array}{l}0.407 \\
0.01\end{array}$ & $\begin{array}{l}0.401 \\
0.01\end{array}$ & $\begin{array}{l}0.521 \\
0.01\end{array}$ & $\begin{array}{l}0.292 \\
0.08\end{array}$ & $\begin{array}{l}0.377 \\
0.02\end{array}$ & $\begin{array}{l}0.163 \\
0.34\end{array}$ & $\begin{array}{l}0.487 \\
0.01\end{array}$ & $\begin{array}{l}0.348 \\
0.04\end{array}$ \\
\hline $\begin{array}{l}\text { Driving } \\
p\end{array}$ & $\begin{array}{l}0.099 \\
0.74\end{array}$ & $\begin{array}{l}0.236 \\
0.42\end{array}$ & $\begin{array}{l}-0.311 \\
0.28\end{array}$ & $\begin{array}{l}-0.550 \\
\mathbf{0 . 0 4}\end{array}$ & $\begin{array}{l}-0.402 \\
0.15\end{array}$ & $\begin{array}{l}0.556 \\
0.04\end{array}$ & $\begin{array}{l}0.338 \\
0.24\end{array}$ & $\begin{array}{l}-0.049 \\
0.87\end{array}$ \\
\hline $\begin{array}{l}\text { Color vision } \\
p\end{array}$ & $\begin{array}{l}0.057 \\
0.74\end{array}$ & $\begin{array}{l}0.112 \\
0.52\end{array}$ & $\begin{array}{l}0.192 \\
0.26\end{array}$ & $\begin{array}{l}0.252 \\
0.14\end{array}$ & $\begin{array}{l}0.087 \\
0.61\end{array}$ & $\begin{array}{l}-0.227 \\
0.18\end{array}$ & $\begin{array}{l}0.203 \\
0.24\end{array}$ & $\begin{array}{l}0.066 \\
0.70\end{array}$ \\
\hline $\begin{array}{l}\text { Peripheral vision } \\
p\end{array}$ & $\begin{array}{l}0.081 \\
0.64\end{array}$ & $\begin{array}{l}0.244 \\
0.15\end{array}$ & $\begin{array}{l}0.341 \\
0.04\end{array}$ & $\begin{array}{l}0.474 \\
0.01\end{array}$ & $\begin{array}{l}0.285 \\
0.09\end{array}$ & $\begin{array}{l}0.092 \\
0.60\end{array}$ & $\begin{array}{l}0.490 \\
0.01\end{array}$ & $\begin{array}{l}0.350 \\
\mathbf{0 . 0 4}\end{array}$ \\
\hline
\end{tabular}

\section{DISCUSSION}

The NEI VFQ-25 is a valid and reliable vision-specific quality of life instrument that has been used to supplement the clinical assessment of various eye diseases ${ }^{(29)}$. Prior studies have reported results from the NEI VFQ-25 among patients with age-related macular degeneration, types 1 and 2 diabetes, glaucoma, optic neuritis, dry eye, uveitis, and central retinal vein occlusion ${ }^{(29)}$.

Reliable assessment of the impact of ophthalmic diseases on the visual-related quality of life must take into account specific cultural aspects of different populations ${ }^{(1)}$. We developed and tested reliability and validity of a Brazilian version of the NEI VFQ-25 in ophthalmic patients and healthy controls.

Regarding reliability, the Brazilian version showed internal consistency (IC) greater than 0.7 , the value that is generally accepted as standard. The IC of all scales of the Brazilian version of NEI VFQ 25 was high. The IC of the original forms of the NEI VFQ-51 and NEI VFQ-25, ranged from 0.66 to 0.94 and 0.71 to 0.85 , respectively. Considering that coefficients above 0.85 are generally accepted as satisfactory ${ }^{(13)}$, our results suggest that our NEI VFQ-25 version has a good internal consistency. The high test-retest reproducibility of the NEI VFQ-25 is a critical characteristic for a questionnaire to be used in follow-up studies ${ }^{(27)}$. A correlation coefficient greater than
0.80 for two administrations of a scale one to two weeks apart suggests adequate stability ${ }^{(27)}$. The test-retest reliability ranged from 0.60 to 0.97 . In the present study, the "General health", "Social function" and "Peripheral vision" had IC $<0.80$, while in the NEI VFQ-51 study the test-retest reliability ranged from 0.68 to 0.91 (data of the NEI VFQ-25 original study were not provided $)^{(12,30)}$.

Interrater reliability represents the agreement between different researchers and correlations may be made between raters' scores for the total scale as well as for individual items ${ }^{(27)}$. In the present study all correlations were greater than 0.80 , the figure considered as acceptable ${ }^{(27)}$.

"Validity pertains whether the scale accurately assesses what it was designed to assess"(1,10,27). We tested the validity of our version by comparison of its subscales with scales of similar content of the SF-36. The "General health" subscale of our version of the NEI VFQ-25 highly correlated with the "General health" of the SF-36. Other scales of the of SF-36 that showed high correlations with our version of the NEI VFQ-25 were "Role emotional" and "Bodily pain", followed by "Physical functioning" and "Vitality " subscales. The remaining subscales of the SF-36 were weakly correspondent to our NEI VFQ-25. Examples of this weak correlation includes SF-36 mental health and NEI VFQ-25 ocular pain which showed nonsignificant correlations, a finding that supports the discriminatory validity. It is also important to notice that the most observed correlations between the NEI VFQ-25 scales and the 


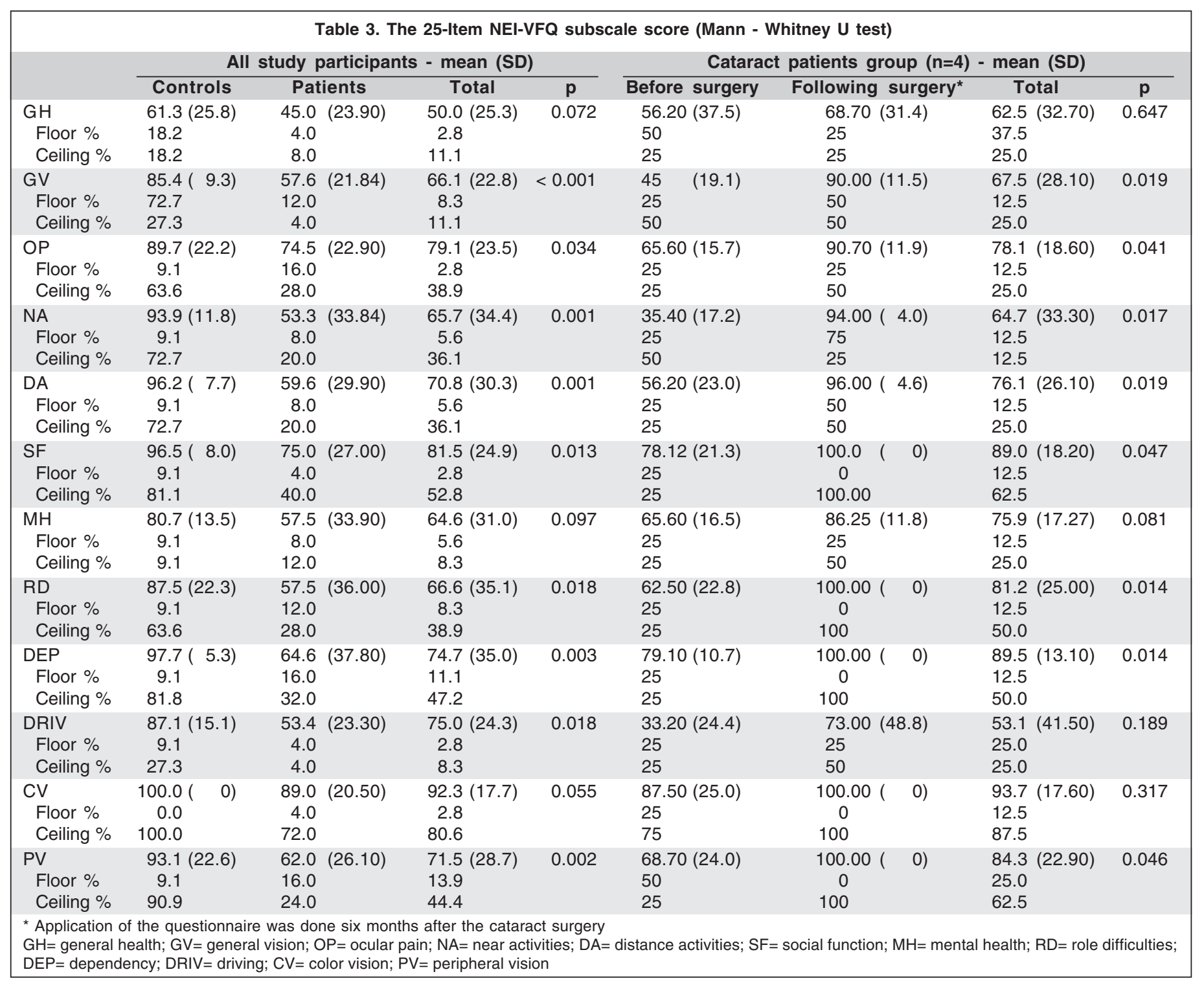

SF-36 were below 0.5 , especially when considering the mental health component (correlations $<0.4$ ). This finding confirms that the two questionnaires are capturing different dimensions of health, what has been observed by others investigators $^{(2,13)}$. Correlations between responses in our version of the NEI VFQ-25 and visual acuity (better and worse eyes) were in the range of 0.45 to 0.69 for subscales that reflected degree of difficulty with central visual function related to "Near vision" and "Distance vision" subscales ${ }^{(12)}$. This correlation for the NEI VFQ-25 original study ranged from 0.66 to 0.69 , for similar subscales ${ }^{(11-12)}$.

The control group had the best scale scores across all dimensions of the NEI VFQ-25 suggesting that the translated questionnaire has a good discriminatory power. This has been also observed in the original version ${ }^{(12)}$.

The 12 interscale correlations represent multiple dimensions of the vision-target HRQOL. The high degree of statis- tical correspondence between the activity-oriented scales such as "Near vision" and "Distance vision" suggests a vision-targeted physician dimension. Conversely, the low correlation for the "General health" subscale with any of the other scales supports that this scale represents a unique additional dimension of the vision-targeted health related quality of life ${ }^{(2,13)}$.

Factor analysis indicated that the most of the subscales that are influenced by central vision correlated with the first factor, while the "General vision", "Ocular pain" and "Peripheral vision" subscales were included in the second factor. These results suggest that almost all subscales of NEI VFQ-25 belong to the same underlying dimension. Similar observation was reported in the Japanese version of this questionnaire ${ }^{(2)}$. The Brazilian version of NEI VFQ-25 proved to be a valuable tool for use in the country as psychometrics properties are correspondent to the original American version. 


\begin{tabular}{|c|c|c|c|c|c|c|c|c|c|c|c|}
\hline & $\begin{array}{l}\text { General } \\
\text { health }\end{array}$ & $\begin{array}{c}\text { General } \\
\text { vision }\end{array}$ & $\begin{array}{l}\text { Ocular } \\
\text { pain }\end{array}$ & $\begin{array}{l}\text { Near } \\
\text { activities }\end{array}$ & $\begin{array}{l}\text { Distance } \\
\text { activities }\end{array}$ & $\begin{array}{l}\text { Social } \\
\text { function }\end{array}$ & $\begin{array}{r}\text { Mental } \\
\text { health }\end{array}$ & $\begin{array}{c}\text { Role } \\
\text { difficulties }\end{array}$ & $\begin{array}{l}\text { Depen- } \\
\text { dency }\end{array}$ & Driving & $\begin{array}{l}\text { Color } \\
\text { vision }\end{array}$ \\
\hline $\begin{array}{l}\text { General vision } \\
p\end{array}$ & $\begin{array}{l}0.32 \\
0.06\end{array}$ & & & & & & & & & & \\
\hline $\begin{array}{l}\text { Ocular pain } \\
p\end{array}$ & $\begin{array}{l}0.31 \\
0.07\end{array}$ & $\begin{array}{l}0.62 \\
0.01\end{array}$ & & & & & & & & & \\
\hline $\begin{array}{l}\text { Near activities } \\
p\end{array}$ & $\begin{array}{l}0.25 \\
0.15\end{array}$ & $\begin{array}{l}0.78 \\
0.01\end{array}$ & $\begin{array}{l}0.50 \\
0.01\end{array}$ & & & & & & & & \\
\hline $\begin{array}{l}\text { Distance activities } \\
p\end{array}$ & $\begin{array}{l}0.27 \\
0.11\end{array}$ & $\begin{array}{l}0.73 \\
0.01\end{array}$ & $\begin{array}{l}0.55 \\
0.01\end{array}$ & $\begin{array}{l}0.71 \\
0.01\end{array}$ & & & & & & & \\
\hline $\begin{array}{l}\text { Social function } \\
p\end{array}$ & $\begin{array}{l}0.23 \\
0.17\end{array}$ & $\begin{array}{l}0.71 \\
0.01\end{array}$ & $\begin{array}{l}0.49 \\
0.01\end{array}$ & $\begin{array}{l}0.72 \\
0.01\end{array}$ & $\begin{array}{l}0.74 \\
0.01\end{array}$ & & & & & & \\
\hline $\begin{array}{l}\text { Mental health } \\
p\end{array}$ & $\begin{array}{l}0.23 \\
0.18\end{array}$ & $\begin{array}{l}0.62 \\
0.01\end{array}$ & $\begin{array}{l}0.64 \\
0.01\end{array}$ & $\begin{array}{l}0.63 \\
0.01\end{array}$ & $\begin{array}{l}0.69 \\
0.01\end{array}$ & $\begin{array}{l}0.75 \\
0.01\end{array}$ & & & & & \\
\hline $\begin{array}{l}\text { Role difficulties } \\
p\end{array}$ & $\begin{array}{l}0.08 \\
0.66\end{array}$ & $\begin{array}{l}0.63 \\
0.01\end{array}$ & $\begin{array}{l}0.48 \\
0.01\end{array}$ & $\begin{array}{l}0.70 \\
0.01\end{array}$ & $\begin{array}{l}0.56 \\
0.01\end{array}$ & $\begin{array}{l}0.75 \\
0.01\end{array}$ & $\begin{array}{l}0.69 \\
0.01\end{array}$ & & & & \\
\hline $\begin{array}{l}\text { Dependency } \\
p\end{array}$ & $\begin{array}{l}0.18 \\
0.29\end{array}$ & $\begin{array}{l}0.69 \\
0.01\end{array}$ & $\begin{array}{l}0.50 \\
0.01\end{array}$ & $\begin{array}{l}0.63 \\
0.01\end{array}$ & $\begin{array}{l}0.68 \\
0.01\end{array}$ & $\begin{array}{l}0.77 \\
0,01\end{array}$ & $\begin{array}{l}0.87 \\
0.01\end{array}$ & $\begin{array}{l}0.74 \\
0.01\end{array}$ & & & \\
\hline $\begin{array}{l}\text { Driving } \\
p\end{array}$ & $\begin{array}{r}-0.39 \\
0.17\end{array}$ & $\begin{array}{l}0.75 \\
0.01\end{array}$ & $\begin{array}{l}0.45 \\
0.11\end{array}$ & $\begin{array}{l}0.71 \\
0.01\end{array}$ & $\begin{array}{l}0.57 \\
0.03\end{array}$ & $\begin{array}{l}0.55 \\
0.04\end{array}$ & $\begin{array}{l}0.50 \\
0.07\end{array}$ & $\begin{array}{l}0.70 \\
0.01\end{array}$ & $\begin{array}{l}0.78 \\
0.01\end{array}$ & & \\
\hline $\begin{array}{l}\text { Color vision } \\
p\end{array}$ & $\begin{array}{l}0.21 \\
0.22\end{array}$ & $\begin{array}{l}0.31 \\
0.06\end{array}$ & $\begin{array}{l}0.23 \\
0.18\end{array}$ & $\begin{array}{l}0.45 \\
0.01\end{array}$ & $\begin{array}{l}0.50 \\
0.01\end{array}$ & $\begin{array}{l}0.59 \\
0.01\end{array}$ & $\begin{array}{l}0.55 \\
0.01\end{array}$ & $\begin{array}{l}0.40 \\
0.02\end{array}$ & $\begin{array}{l}0.62 \\
0.01\end{array}$ & $\begin{array}{l}0.21 \\
0.47\end{array}$ & \\
\hline $\begin{array}{l}\text { Peripheral vision } \\
p\end{array}$ & $\begin{array}{l}0.45 \\
0.01\end{array}$ & $\begin{array}{l}0.59 \\
0.01\end{array}$ & $\begin{array}{l}0.45 \\
0.01\end{array}$ & $\begin{array}{l}0.53 \\
0.01\end{array}$ & $\begin{array}{l}0.71 \\
0.01\end{array}$ & $\begin{array}{l}0.68 \\
0.01\end{array}$ & $\begin{array}{l}0.59 \\
0.01\end{array}$ & $\begin{array}{l}0.49 \\
0.01\end{array}$ & $\begin{array}{l}0.58 \\
0.01\end{array}$ & $\begin{array}{l}0.63 \\
0.02\end{array}$ & $\begin{array}{l}0.43 \\
0.01\end{array}$ \\
\hline
\end{tabular}

To demonstrate the psychometric properties of the Brazilian version we used a more complete analysis including interrater reliability visual acuity versus composite score, and factor analysis which have not been thoroughly employed in other validation studies ${ }^{(2,13,15)}$.

We also tested the ability of our version of the NEI-VFQ 25 questionnaire to detect meaningful change over time (responsiveness) in a group of patients before and following cataract surgery. Four participants submitted to surgery and were reinterviewed by the end of this study. All of them improved visual acuity after the procedure. Few reports are available on the responsiveness of the NEI VFQ-25(2,30). Our findings showed a better score following surgery suggesting the NEI VFQ25 as a discriminative instrument suitable to detect such changes in patients with ophthalmic disease.

\section{CONCLUSION}

The herein introduced Brazilian version of the NEI VFQ-25 questionnaire showed psychometrics properties comparable to the American original version, with high reliability and validity. It provides for Brazilian investigators an important tool to assess the impact of ophthalmic conditions and effects of therapeutic interventions on the vision-related quality of life of their patients.

\section{RESUMO}

Objetivo: Desenvolver e investigar a confiabilidade e a validade da versão brasileira do Questionário de Função Visual de
25 Itens do National Eye Institute. Métodos: A versão brasileira do questionário foi desenvolvida e aplicada em pacientes com doenças oculares crônicas e controles sadios. A confiabilidade foi calculada pelo coeficiente alfa de Cronbach de correlação intraclasse e de confiabilidade entre examinadores. Foi usado o questionário "The Medical Outcomes Study Short Form-36". A validade foi calculada pela correlação entre as escalas dos questionários e entre as 12 subescalas do questionário, a pontuação das subescalas e a acuidade visual, a pontuação das subescalas de pacientes e controles e a análise fatorial. A validação do questionário foi calculada em grupo de pacientes antes e após cirurgia de catarata. Resultados: $\mathrm{O}$ coeficiente de alfa de Cronbach, de correlação intraclasse e de variação entre entrevistadores, e os testes de validade da versão brasileira foram significantes. A responsividade foi confirmada pela melhora na qualidade de vida visual no grupo submetido à cirurgia de catarata. Conclusão: A versão brasileira do Questionário de Função Visual de 25 Itens apresenta propriedades psicométricas válidas e confiáveis e pode ser aplicado em pesquisa de qualidade de vida visual.

Descritores: Qualidade de vida; Estudos de validação; Questionários; Brasil

\section{REFERENCES}

1. Stelmack J. Quality of life of low-vision patients and outcomes of low-vision rehabilitation. Optom Vis Sci. 2001;78(5):335-42.

2. Suzukamo Y, Oshika T, Yuzawa M, Tokuda Y, Tomidokoro A, Oki K, et al. Psychometric properties of the 25-Item National Eye Institute Visual Function 
Questionnaire (NEI VFQ-25), Japanese version. Health Qual Life Outcomes. 2005;3:65.

3. Torres X, Arroyo S, Araya S, de Pablo J. The Spanish Version of the Qualityof-Life in Epilepsy Inventory (QOLIE-31): translation, validity, and reliability. Epilepsia. 1999;40(9):1299-304.

4. Benedict RH, Wahlig E, Bakshi R, Fishman I, Munschauer F, Zivadinov R, et al. Predicting quality of life in multiple sclerosis: accounting for physical disability, fatigue, cognition, mood disorder, personality, and behavior change. J Neurol Sci. 2005;231(1-2):29-34.

5. Scott IU, Schein OD, West S, Bandeen-Roche K, Enger C, Folstein MF. Functional status and quality of life measurement among ophthalmic patients. Arch Ophthalmol. 1994;112(3):329-35.

6. Lundström M, Fregell G, Sjöblom A. Vision related daily life problems in patients waiting for a cataract extraction. Br J Ophthalmol. 1994;78(8):608-11

7. Klein BE, Klein R, Jensen SC. A short questionnaire on visual function of older adults to supplement ophthalmic examination. Am J Ophthalmol. 2000; 130(3):350-2

8. Nelson P, Aspinall P, Papasouliotis O, Worton B, O'Brien C. Quality of life in glaucoma and its relationship with visual function. J Glaucoma. 2003; 12(2):139-50.

9. Brown GC. Vision and quality-of-life. Trans Am Ophthalmol Soc. 1999;97:473-511.

10. Mangione CM, Lee PP, Pitts J, Gutierrez P, Berry S, Hays RD. Psychometric properties of the National Eye Institute Visual Function Questionnaire (NEI-VFQ) NEI-VFQ Field Test Investigators. Arch Ophthalmol. 1998; 116(11):1496-504.

11. Mangione CM, Berry S, Spritzer K, Janz NK, Klein R, Owsley C, et al Identifying the content area for the 51-Item National Eye Institute Visual Function Questionnaire: results from focus groups with visually impaired persons. Arch Ophthalmol. 1998;116(2):227-33

12. Mangione CM, Lee PP, Gutierrez PR, Spritzer K, Berry S, Hays RD; National Eye Institute Visual Function Questionnaire Field Test Investigators. Development of the 25-Item National Eye Institute Visual Function Questionnaire. Arch Ophthalmol. 2001;119(7):1050-8.

13. Rossi GC, Milano G, Tinelli C. The Italian version of the 25-Item National Eye Institute Visual Function Questionnaire: translation, validity, and reliability. J Glaucoma. 2003;12(3):213-20.

14. Nordmann JP, Viala M, Sullivan K, Arnould B, Berdeaux G. Psychometric Validation of the National Eye Institute Visual Function Questionnaire - 25 (NEI VFQ-25) French version: in a population of patients treated for ocular hypertension and glaucoma. Pharmacoeconomics. 2004;22(3):197-206.

15. Broman AT, Munoz B, West SK, Rodriguez J, Sanchez R, Snyder R, Klein R. Psychometric properties of the 25-Item NEI-VFQ in a Hispanic population: Proyecto VER. Invest Ophthalmol Vis Sci. 2001;42(3):606-13.

16. Toprak AB, Eser E, Guler C, Baser FE, Mayali H. Cross-validation of the Turkish version of the 25-Item National Eye Institute Visual Functioning Questionnaire (NEI-VFQ 25). Ophthalmic Epidemiol. 2005;12(4):259-69.
17. Franke GH, Esser J, Reimer J, Maehner N. Vision targeted quality of life under different degrees of vision impairment. Rev Port Psicossom. 2002;4(1):39-49.

18. Atique D, Goulart DG, Lake JC, Lima FA, Felberg S, Nishiwaki-Dantas MC Qualidade de vida após transplante penetrante de córnea. Arq Bras Oftalmol. 2002;65(3):351-4

19. Nogueira R, França M, Lobato MG, Universidade Federal de São Paulo, Souza CB, Gomes JAP. Qualidade de vida dos pacientes portadores de síndrome de Stevens-Johnson. Arq Bras Oftalmol. 2003;66(1):67-70.

20. Nunes LM, Cortizo V, Schor P. Validação de versão em língua portuguesa do questionário NEI-RQL como instrumento de avaliação da qualidade de vida relacionada à visão, em candidatos a cirurgia refrativa. Rev Bras Oftalmol. 2004;63(2):110-8

21. Ferraz EVAP, Lima CA, Cella W, Arieta CEL. Adaptação de questionário de avaliação da qualidade de vida para aplicação em portadores de catarata. Arq Bras Oftalmol. 2002;65(3):293-8.

22. Ciconelli RM. Tradução para o português e validação do questionário genérico de avaliação de qualidade de vida "Medical Outcomes Study 36-Item ShortForm Health Survey (SF-36)". (Tese). São Paulo: Universidade Federal de São Paulo. Escola Paulista de Medicina; 1997.

23. Ware JE Jr, Sherbourne CD. The MOS 36-Item short-form health survey (SF-36). I. Conceptual framework and item selection. Med Care. 1992;30(6): 473-83.

24. McHorney CA, Ware JE Jr, Raczek AE. The MOS 36-Item Short-Form Health Survey (SF-36): II. Psychometric and clinical tests of validity in measuring physical and mental health constructs. Med Care. 1993;31(3):247-63.

25. McHorney CA, Ware JE Jr, Lu JF, Sherbourne CD. The MOS 36-Item ShortForm Health Survey (SF-36): III. Tests of data quality, scaling assumptions, and reliability across diverse patient groups. Med Care. 1994;32(1):40-66.

26. Araujo CR, Simão LM, Ybarra MI, Faria NV, Botelho CM, Moreira MA, et al. Validation of the Brazilian version of Guy's neurological disability scale. Arq Neuropsiquiatr. 2007;65(3A):615-8.

27. Myers K, Winters NC. Ten-year review of rating scales. I: overview of scale functioning, psychometric properties, and selection. J Am Acad Child Adolesc Psychiatry. 2002;41(2):114-22.

28. Hair J, Anderson RE, Tatham RL, Black WC. Multivariate data analysis: with readings. $4^{\text {th }}$ ed. Englewood Cliffs, N.J.: Prentice Hall; c1995.

29. Cusick M, SanGiovanni JP, Chew EY, Csaky KG, Hall-Shimel K, Reed GF, et al. Central visual function and the NEI-VFQ-25 near and distance activities subscale scores in people with type 1 and 2 diabetes. Am J Ophthalmol. 2005;139(6):1042-50.

30. Miskala PH, Hawkins BS, Mangione CM, Bass EB, Bressler NM, Dong LM, Marsh MJ, McCaffrey LD; The Submacular Surgery Trials Research Group. Responsiveness of the National Eye Institute Visual Function Questionnaire to changes in visual acuity: findings in patients with subfoveal choroidal neovascularization-SST Report № 1. Arch Ophthalmol. 2003;121(4):531-9. Erratum in: Arch Ophthalmol. 2003;121(10):1513. 